\title{
HUBUNGAN PERSEPSI IBU DENGAN IMUNISASI CAMPAK PADA BAYI USIA DI ATAS 9 BULAN DI POSYANDU MOJOWUKU SLEMPIT GRESIK
}

\author{
Imandra Arif Bachtiar*, Chilyatiz Zahroh** \\ Program Studi S1 Keperawatan \\ Fakultas Keperawatan dan Kebidanan \\ Universitas Nahdlatul Ulama Surabaya
}

\begin{abstract}
Abstrack : The habitual of Some mothers living around Posyandu Mojowuku tend not to provide their babies with measles immunization because of the perception that measles immunization can cause fever in babies. The fact that they do not receive information about immunization from the health workers creates a wrong perception that brings bad effects to babies. Hence, the purpose of this study was to find out the correlation between mother's perception and measles immunization in babies aged over 9 months.

This study was cross sectional approach involved the population of all mothers having babies aged over 9 months, totaling 63 couples. The samples of research 54 respondents were chosen using Non Probability sampling and Purposive sampling technique. Questionnaire and maternal-child health booklet were used to collect the data. Analyzed using Chi-Square test with the level of significance a $=0.05$.

The result showed that most of the mothers (66.7\%) had positive perception about measles immunization, whereas most of the babies (70.4\%) received measles immunization. Moreover, the result of Chi-Square test showed that $\rho=0,000<$ so that $H_{0}$ was rejected illustrating that there was a correlation between mother's perception and measles immunization in babies aged over 9 months.

Mother's perception significantly affected the coverage of measles immunization in babies. Hence, those who have negative perception about measles immunization are expected to change their opinion and perception to avoid dangers for their babies. Moreover, the health workers are also expected to promote activities of providing them with health education to increase their awareness of measles immunization.
\end{abstract}

Key words: mother's perception, measles immunization, baby's

Abstrak : Fenomena di Posyandu Mojowuku didapatkan ibu cenderung tidak mengimunisasi campak bayinya, hal tersebut dikarenakan ibu mengerti dampak setelah imunisasi campak bisa menimbulkan bayi menjadi demam. Ibu di Posyandu Mojowuku tidak mendapat penjelasan tentang imunisasi dari petugas posyandu. Hal tersebut menyebabkan persepsi yang salah, kemudian persepsi yang salah tersebut akan menimbulkan dampak yang buruk bagi bayi. Tujuan penelitian ini untuk mengetahui hubungan persepsi ibu dengan imunisasi campak pada bayi usia di atas 9 Bulan.

Desain penelitian menggunakan analitik dengan Cross Sectional. Variabel dependent dalam skripsi ini adalah persepsi ibu dan Imunisasi campak sebagi Variabel independent. Populasi dalam penelitian ini adalah seluruh ibu dan bayi usia diatas 9 bulan sebanyak 63 pasang responden. Sampel penelitian sebanyak 54 pasang responden didapatkan dari teknik Non Problablity Sampling dan tehnik Purposive Sampling. Instrumen yang digunakan yaitu kuesioner tentang persepsi ibu dan buku KIA. Analisis yang digunakan uji Chi-Square pada tingkat kemaknaan $\alpha=0,05$.

Hasil penelitian menunjukkan bahwa sebagian besar (66.7\%) persepsi positif dan sebagian besar (70.4\%) mendapat imunisasi campak. Hasil uji Chi-Square didapatkan $\rho=0,000 \leq \alpha=0,005$ maka $\mathrm{H}_{0}$ ditolak yang berarti ada hubungan persepsi ibu dengan imunisasi campak pada bayi usia di atas 9 bulan.

Persepsi ibu sangat mempengaruhi cakupan imunisasi campak pada bayi. Imunisasi campak berperan penting dalam membentuk kekebalan tubuh bayi. Sebagian kecil ibu memiliki persepsi negatif 
tentang imunisasi campak. Untuk ibu diharapkan mengubah panilaian dan pandangan terhadap Imunisasi campak sehingga tidak menjadikan hal yang membahayakan kesehatan bayi.

Kata kunci : Persepsi ibu, Imunisasi campak, Bayi

\section{PENDAHULUAN}

Fenomena di Posyandu Mojowuku didapakan ibu masih cenderung tidak mengimunisasikan bayinya, hal tersebut dikarenakan efek dari imunisasi campak bisa menimbulkan bayi menjadi demam atau bisa juga berdampak kejang pada bayi, peran dari petugas kesehatan juga kurang dari harapan. Ibu datang di Posyandu Mojowuku tidak mendapat penjelasan tentang imunisasi dari petugas posyandu atau petugas kesehatan. Hal tersebut menyebabkan persepsi yang salah, kemudian persepsi yang salah tersebut akan menimbulkan dampak yang buruk bagi bayi.

Studi pendahuluan yang dilakukan di Desa Slempit, di dapatkan data cakupan imunisasi selama awal tahun tahun 2016 adalah BCG sebesar $94.7 \%$, Hepatitis B sebesar $90.5 \%$, Polio I, II, III total sebesar 91,8\%, DPT 91,3\%, Campak $81,9 \%$. Berdasarkan cakupan imunisasi tersebut maka dapat dinyatakan bahwa cakupan imunisasi di Desa Sumput menurun, termasuk yang sangat drastis dari bulan sebelumnya yang berkisar $22,4 \%$ penurunannya adalah imunisasi campak.

Dampak dari tidak imunisasi adalah anak tidak mempunyai kekebalan spesifik. Jika anak tidak punya kekebalan spesifik, anak akan mudah terserang penyakit berbahaya, sistem imun anak menjadi lemah, anak akan mudah sakit bahkan kematian atau kecacatan. Vaksin akan membentuk kekebalan spesifik dalam tubuh bayi (Soedjatmiko, 2014). Tidak ada satu dari jenis vaksin yang aman tanpa efek samping, maka apabila seorang anak telah mendapatkan imunisasi perlu diobsevasi beberapa saat, sehingga dipastikan tidak terjadi KIPI (reaksi cepat).

Perawat berperan penting dalam memberikan informasiuntuk membentuk persepsi positif terhadap manfaat imunisasi, hal tersebut akan meningkatkan persepsi ibu untuk membawa bayinya ke Puskesmas, Posyandu dan fasilitas kesehatan lain untuk mendapatkan imunisasi dan orang tua memahami tentang manfaat serta dampak dari imunisasi. Bersama melakukan percepatan upaya, penguatan program imunisasi rutin, mendukung upaya pengembangan vaksin yang lebih baik.

\section{METODE PENELITIAN}

Desain penelitian menggunakan analitik dengan Cross Sectional. Populasi dalam penelitian ini adalah seluruh ibu dan bayi usia diatas 9 bulan sebanyak 63 pasang responden. Sampel penelitian sebanyak 54 pasang responden didapatkan dari teknik Non Problablity Sampling dengan tehnik Purposive Sampling Variabel dependent dalam skripsi ini adalah persepsi ibu dan Imunisasi campak sebagai variabel independent. Instrumen yang digunakan yaitu kuesioner tentang persepsi ibu dan buku KIA. Analisis yang digunakan uji Chi-Square pada tingkat kemaknaan $\alpha=0,05$. Hasil interpretasi digunakan untuk mengelompokkan peran responden termasuk dalam berperan bila nilai skor $\mathrm{T}$ responden $>$ mean $\mathrm{T}$ dan tidak berperan apabila nilai skor $\mathrm{T}$ responden $<$ mean $\mathrm{T}$ (Anwar, 2010).

\section{HASIL PENELITIAN}

1. Data Umum

a. Karakteristik responden berdasarkan umur ibu

\begin{tabular}{ccc}
\hline Umur (Tahun) & Frekuensi & Persentase \\
\hline Remaja akhir(17-25) & 15 & $27.8 \%$ \\
Dewasa awal(26-35) & 28 & $51.9 \%$ \\
Dewasa akhir(36-45) & 11 & $20.4 \%$ \\
\hline Total & 54 & $100.0 \%$ \\
\hline
\end{tabular}

Sumber : Data Primer April 2016

Tabel 5.1 Distribusi frekuensi Responden berdasarkan umur (Ibu) di Dusun Mojowuku, Desa Slempit, Kecamatan Kedamean April 2016.

Hasil penelitian di tabel 5.1 menunjukkan bahwa dari 54 responden di Dusun Mojowuku, Desa Slempit, Kecamatan Kedamean, Gresik sebagian besar (51.9\%) berumur 26-35 tahun. b. Karakteristik responden berdasarkan pendidikan 


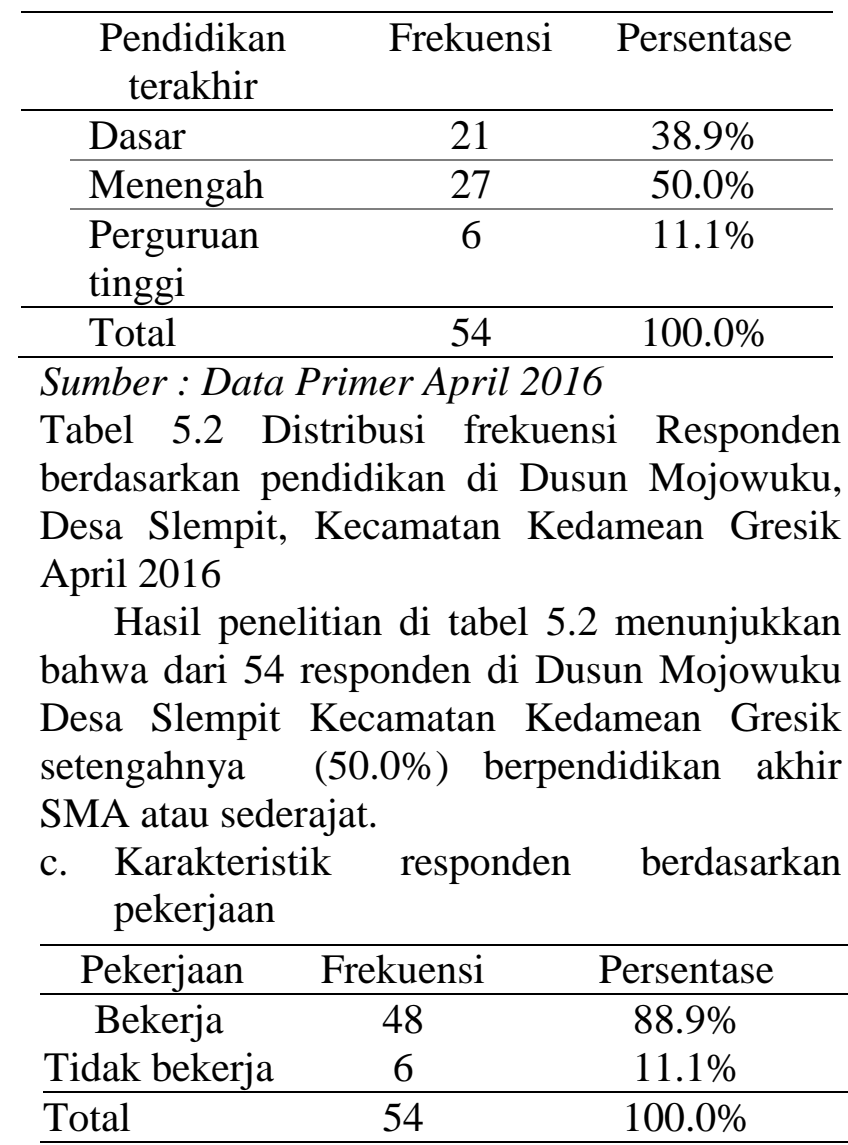

Sumber : Data Primer April 2016

Tabel 5.3 Distribusi frekuensi Responden bedeasarkan Pekerjaan di Dusun Mojowuku Desa Slempit Kecamatan Kedamean Gresik April 2016

Hasil penelitian di tabel 5.3 menunjukkan bahwa dari 54 responden di Dusun Mojowuku Desa Slempit Kecamatan Kedamean Gresik hampir seluruhnya (88.9\%) Ibu bekerja.

2. Data khusus

Data ini menampilkan karakteristik responden berdasarkan persepsi ibu, cakupan imunisasi campak, tabulasi silang anatara persepsi dan Imunisasi campak beserta ujinya.

a. Karakteristik responden berdasarkan persepsi ibu terhadap imunisasi campak.

\begin{tabular}{ccc}
\hline Persepsi & Frekuensi & Persentase \\
\hline Positif & 36 & $66.7 \%$ \\
Negatif & 18 & $33.3 \%$ \\
\hline Total & 54 & 100.0
\end{tabular}

Sumber : Data Primer April 2016

Tabel 5.5 Distribusi freskuensi responden berdasarkan persepsi ibu terhadap Imunisasi campak di Dusun Mojowuku Desa Slempit Kecamatan Kedamean Gresik April 2016
Hasil penelitian di tabel 5.5 menunjukkan bahwa dari 54 pasang responden (Ibu) di Dusun Mojowuku Desa Slempit Kecamatan Kedamean Gresik sebagian besar (74.1\%) memiliki persepsi positif terhadap Imunisasi Campak dan sebagian kecil $(25.9 \%)$ memiliki persepsi negatif

b. Karakteristik responden berdasarkan cakupan Imunisasi Campak bayi usia di atas 9 Bulan

\begin{tabular}{lcc}
\hline Imunisasicampak & Frekuensi & Persentase \\
\hline Mendapat & 38 & $70.4 \%$ \\
Tidakmendapat & 16 & $29.6 \%$ \\
\hline Total & 54 & $100.0 \%$ \\
\hline
\end{tabular}

Sumber : Data Primer April 2016

Tabel 5.6 Distribusi freskuensi responden berdasarkan cakupan Imunisasi campak pada bayi usia di atas 9 bulan di Dusun Mojowuku Desa Slempit Kecamatan Kedamean Gresik April 2016

Hasil penelitian di tabel 5.6 menunjukkan bahwa dari 54 pasang responden (Bayi) di Dusun Mojowuku Desa Slempit Kecamatan Kedamean Gresik sebagian besar (68.5\%) mendapat Imunisasi campak.

c. Karakteristik responden berdasarkan tabulasi silang antara persepsi dengan Imunisasi campak.

\section{Sumber : Data Primer April 2016}

\begin{tabular}{|c|c|c|c|c|}
\hline \multirow{2}{*}{\multicolumn{2}{|c|}{$\begin{array}{l}\text { Persepsi * } \\
\text { Imunisasi_Campak } \\
\text { Crosstabulation }\end{array}$}} & \multicolumn{2}{|c|}{ Imunisasi_Campak } & \multirow[t]{2}{*}{ Total } \\
\hline & & Mendapat & $\begin{array}{c}\text { Tidak } \\
\text { Mendapat }\end{array}$ & \\
\hline P Pos & Count & 36 & 0 & 36 \\
\hline \multirow{2}{*}{$\begin{array}{l}\mathrm{e} \\
\mathrm{r}\end{array}$} & $\%$ within & $100.0 \%$ & $0.0 \%$ & $100.0 \%$ \\
\hline & Persepsi & & & \\
\hline \multirow{2}{*}{$\begin{array}{ll}\mathrm{s} & \mathrm{Neg} \\
\mathrm{e}\end{array}$} & Count & 2 & 16 & 18 \\
\hline & $\%$ within & $11.1 \%$ & $88.9 \%$ & $100.0 \%$ \\
\hline $\begin{array}{l}\mathrm{p} \\
\mathrm{s}\end{array}$ & Persepsi & & & \\
\hline \multicolumn{5}{|l|}{$\mathrm{i}$} \\
\hline \multirow[t]{2}{*}{ Total } & Count & 38 & 16 & 54 \\
\hline & $\begin{array}{l}\% \text { within } \\
\text { Persepsi }\end{array}$ & $70.4 \%$ & $29.6 \%$ & $100.0 \%$ \\
\hline
\end{tabular}

Tabel 5.7 Distribusi freskuensi responden berdasarkan tabulasi silang antara persepsi dengan Imunisasi campak di Dusun Mojowuku Desa Slempit Kecamatan Kedamean Gresik April 2016 
Hasil penelitian pada tabel 5.7 di atas dari 36 responden yang mempunyai persepsi positif $36(100 \%)$ responden mendapat imunisasi campak. Dari 18 responden yang mempunyai persepsi negatif sebagian kecil 2 (11.1\%) responden mendapat imunisasi campak. Sedangkan dari 18 responden yang mempunyai persepsi negatif hampir seluruhnya $16(88.9 \%)$ responden tidak mendapat imunisasi campak.

Berdasarkan uji Chi-Square program SPSS 21 for windows didapatkan tingkat signifikasi $\mathrm{p}$ $=0.000 \leq(\alpha=0,005)$ yang berarti Ho ditolak artinya ada hubungan antara persepsi ibu dengan imunisasi campak pada bayi usia di atas 9 bulan di Dusun Mojowuku Desa Slempit Kecamatan Kedamean Gresik.

\section{PEMBAHASAN}

1. Persepsi ibu di wilayah Posyandu Mojowuku

Hasil penelitian berdasarkan tabel 5.5 menyatakan bahwa persepsi ibu terhadap Imunisasi Campak di Dusun Mojowuku Desa Slempit Kecamatan Kedamean Gresik sebagian besar $36(66.7 \%)$ memiliki persepsi positif. Hal ini menunjukkan bahwa sebagian besar ibu mengerti tentang efek samping dari imunisasi campak yang akan membentuk kekebalan pada tubuh anak terhadap suatu penyakit khususnya penyakit campak. Robbins (2006) mengemukakan bahwa persepsi positif merupakan penilaian individu terhadap suatu objek atau informasi dengan pandangan yang positif atau sesuai dengan yang diharapkan dari objek yang dipersepsikan atau dari aturan yang ada.

Sedangkan sebagian kecil 18 (33.3\%) ibu memiliki persepsi negatif, sebagian ibu masih menganggap bahwa imunisasi campak akan berdampak negatif bagi bayi. Misalnya, ibu cenderung tidak mengimunisasikan campak untuk bayinya dikarenakan efek samping dari Imunisasi campak bisa menyebabkan kejang pada bayi. Persepsi negatif merupakan persepsi individu terhadap objek atau informasi tertentu dengan pandangan yang negatif, berlawanan dengan yang diharapkan dari objek yang dipersepsikan atau dari aturan yang ada. Penyebab munculnya persepsi negatif seseorang dapat muncul karena adanya ketidakpuasan individu terhadap objek yang menjadi sumber persepsinya (Robbins, 2006).

Bedasarkan tabel 5. 1 tentang usia responden masuk pada faktor internal yaitu fisiologis yang terdiri dari umur, jenis kelamin, dll. Didapatkan bahwa sebagian besar $(51.9 \%)$ berumur dewasa awal antara 26-35 tahun. Usia sedemikian masuk usia dewasa awal, dimana kemampuan mempersepsikan Imunisasi Campak sudah cukup baik, seiring dengan kematangan berfikir mereka. Nursalam (2010) mengemukakan bahwa semakin cukup umur seseorang maka tingkat kematangan dan kekuatan akan lebih matang dalam berfikir. Namun kenyataannya semakin tinggi umur bukan jaminan dalam mempersepsikan suatu kejadian atau peristiwa itu akan menjadi baik.

Berdasarkan tabel 5.2 pendidikan juga mempengaruhi persepsi ibu tentang imunisasi campak. Hasil penelitian menunjukkan bahwa setengahnya $(50 \%)$ berpendidikan akhir menengah atau sederajat. Pendidikan ibu sangat berpengaruh terhadap sikap ibu tentang imunisasi campak pada bayi. Orangtua yang mempunyai latar belakang pendidikan yang tinggi akan lebih memperhatikan segala perubahan dan setiap perkembangan yang terjadi pada bayi, dengan pendidikan tinggi orang tua mempunyai pengetahuan yang cukup sehingga dapat memberikan sikap yang baik pada bayi. Menurut Edwards (2006) menyatakan bahwa tingkat pendidikan orangtua serta pengalaman sangat berpengaruh dalam bersikap, seperti terlibat aktif mengamati segala sesuatu dengan berorientasi pada masalah kesehatan bayi, selalu menilai perkembangan fungsi keluarga dalam kesehatan bayinya.

2. Imunisasi campak pada bayi usia di atas 9

Bulan di wilayah Posyandu Mojowuku

Berdasarkan hasil penelitian pada bayi usia diatas 9 bulan di Dusun Mojowuku Slempit Gresik pada tabel 5.6 didapatkan bahwa sebagian besar $38(66,7 \%)$ bayi mendapat Imunisasi campak. Hal ini menunjukkan bahwa orang tua atau ibu mengerti tentang kejadian pasca diberikan imunisasi campak bayi menjadi demam dan ibu menganggap kejadian biasa. Kemudian ibu memberikan Imunisasi Campak 
pada bayinya sesuai dengan jadwal dan ketentuan medis. Ibu juga mengetahui manfaat Imunisasi campak untuk mencegah ataupun menghindari terjadinya penyakit campak. Meskipun campak merupakan penyakit yang terjadi satu kali seumur hidup, namun jika penyakit ini tidak ditangani sangatlah berbahaya. Dimana dapat beresiko kematian. Maka dari itu Imunisasi campak sangat penting untuk dilakukan (Ranuh, 2008).

Hasil penelitian menunjukkan bahwa hampir setengah $18(33,3 \%)$ bayi tidak mendapat Imunisasi campak. Ibu berpendapat bahwa jika bayi diberikan Imunisasi campak maka bayi akan mengalami reaksi pasca Imunisasi, misalnya demam tinggi disertai kejang dan terbentuknya ruam pada bayi. Apabila bayi tidak diberikan Imunisasi campak maka bayi akan mudah terserang penyakit campak. Ranuh (2008) berpendapat bahwa pemberian Imunisasi campak dilakukan pada saat berusia 9 bulan. Meskipun campak hanya menyerang satu kali seumur hidup, namun penyakit ini sangatlah berbahaya dan dapat menimbulkan kematian jika sudah terjadi komplikasi seperti radang otak ataupun radang paru-paru.

Berdasarkan tabel 5.3 menunjukkan bahwa pekerjaan ibu adalah faktor yang mempengaruhi Imunisasi, didapatkan hampir seluruhnya 48 $(88,9 \%)$ ibu bekerja. Hal tersebut menunjukkan bahwa aktivitas ibu di wilayah Posyandu Mojowuku bekerja sebagai petani, kesibukan tersebut dilakukan semata-mata untuk mendapatkan materi untuk mencari tambahan nafkah keluarganya. Keterbatasan waktu menjadi kendala bagi ibu untuk mengenal apa itu pentingnya imunisasi, sehingga menyebabkan hal yang membahayakan bayi. Untuk persepsi ibu tentang Imunisasi campak kepada bayi sangat bergantung dengan siapa mereka bergaul, apabila lingkungan mereka dari lingkungan medis tentu berpengaruh positif terhadap persepsi mereka. Willy F. Maramis (2006) mengemukakan bahwa orang lain disekitar kita merupakan salah satu diantara komponen sosial yang ikut mempengaruhi persepsi kita. Seseorang yang dianggap penting, maka bentuk pemikiran dan sikap tingkah lakunya akan banyak memberikan pengaruh pembentukan persepsi terhadap sesuatu. Orang yang biasanya dianggap penting bagi individu, diantaranya adalah orangtua, orang yangstatus sosialnya lebih tinggi, teman sebaya, teman dekat, teman kerja, guru, istri atau suami,dll.

Upaya meningkatkan pemahaman tentang imunisasi campak pada bayi sebenarnya mudah, yakni dengan bertanya pada pihak-pihak yang berkopetensi dalam bidangnya, misalnya bidan. Tenaga medis ini sangat mudah dijumpai dimanapun. Informasi juga bisa didapatkan dengan memanfaatkan teknoloi tinggi, dimana internet bisa diakses untuk segala ilmu pengetahuan, tergantung ada atau tidaknya kemauan seseorang.

3. Hubungan persepsi ibu dengan kelengkapan imunisasi campak pada bayi usia di atas 9 Bulan di wilayah Posyandu Mojowuku.

Hasil penelitian hubungan persepsi ibu dengan imunisasi campak pada bayi usia diatas 9 bulan di posyandu mojowuku slempit gresik dilakukan dengan menggunakan uji korelasi ChiSquare dengan tingkat kemaknaan $\alpha=0,05$. Perhitungan menggunakan SPSS 21 for windows didapatkan nilai $\rho=0,000$ dan $\alpha=0,05$, maka $\rho<$ $\alpha$ sehingga $\mathrm{H}_{0}$ ditolak yang menyatakan bahwa ada hubungan persepsi ibu dengan imunisasi campak pada bayi usia diatas 9 bulan di posyandu mojowuku slempit gresik

Berdasarkan tabel 5.7 dari 36 responden yang mempunyai persepsi positif seluruhnya $(100,0 \%)$ bayi mendapat imunisasi campak. Hal ini menunjukkan bahwa dari 36 ibu seluruhnya $(100,0 \%)$ memberikan imunisasi campak pada bayinya. Hal ini menunjukkan bahwa ibu yang mempunyai persepsi positif beranggapan bahwa imunisasi campak penting dalam membentuk kekebalan tubuh bayi, ibu juga mengerti tentang kejadian pasca imunisasi yang timbul setelah imunisasi campak tersebut dan menganggap kejadian biasa yang bisa ditangani oleh tenaga kesehatan (Bidan). Robbins (2006) mengemukakan bahwa persepsi positif merupakan penilaian individu terhadap suatu objek atau informasi dengan pandangan yang positif atau sesuai dengan yang diharapkan dari objek yang dipersepsikan atau dari aturan yang ada. Dari jumlah imunisasi campak yang didapat diatas yang seluruhnya mendapat imunisasi 
campak maka hal ini menunjukkan bahwa orangtua atau ibu menganggap imunisasi penting bagi bayinya. Ibu memberikan imunisasi campak pada bayi sesuai dengan jadwal dan ketentuan medis. Imunisasi campak pada bayi yaitu untuk mencegah ataupun menghindari terjadinya penyakit campak. Meskipun campak merupakan penyakit yang terjadi satu kali seumur hidup, namun jika penyakit ini tidak ditangani sangatlah berbahaya. Dimana dapat beresiko kematian. Maka dari itulah imunisasi campak sangat penting untuk dilakukan (Ranuh, 2008).

Berdasarkan tabel 5.7 dari 18 responden yang mempunyai persepsi negatif sebagian kecil $2(11,1 \%)$ responden mendapat imunisasi campak dan hampir seluruhnya $16 \quad(88,9 \%)$ responden tidak mendapat imunisasi campak. Hal ini menunjukkan bahwa sebagian kecil ibu yang mempunyai persepsi negatif tetapi didapatkan 2 orang masih mengimunisasi campak bayinya. Hal tersebut dikarenakan ibu yang kurang meluangkan waktunya untuk bayinya karena sibuk bekerja, kurangnya informasi yang didapat tentang imunisasi. Karena itu bayi lebih sering di asuh oleh neneknya, dan neneknya juga yang mengimunisasikan bayinya. Persepsi negatif bukan berarti mempengaruhi dapatan imunisasi campak pada bayi, hal ini bisa dikarenakan faktor-faktor tertentu seperti kurangnya waktu karena sibuk bekerja, kurangnya transportasi dan kurang informasi tentang kegiatan Posyandu. Ibu yang mempunyai persepsi negatif berpendapat bahwa jika bayi diberikan imunisasi campak maka bayi akan mengalami reaksi pasca imunisasi, misalnya demam tinggi disertai kejang dan terbentuknya ruam pada bayi. Apabila bayi tidak diberikan imunisasi campak maka bayi akan mudah terserang penyakit campak dan bayi tidak mempunyai kekebalan spesifik pada tubunya. Jika bayi tida mempunyai kekebalan spesifik maka sistem imun bayi menjadi lemah, bayi akan mudah sakit bahkan kematian atau kecatatan (Soedjatmiko, 2014).

\section{KESIMPULAN}

A. Simpulan

Simpulan yang didapatkan dari hasil penelitian dan pembahasan mengenai hubungan persepsi ibu dengan Imunisasi Campak di Posyandu Mojowuku Slempit Gresik, sebagai berikut :

1. Sebagian besar ibu memiliki persepsi positif tentang imunisasi campak di Posyandu Mojowuku Slempit Gresik.

2. Bayi usia diatas 9 bulan sebagian besar mendapat imunisasi campak.

3. Ada hubungan persepsi ibu dengan imunisasi campak pada bayi usia diatas 9 bulan di Posyandu Mojowuku Slempit Gresik.

B. Saran

1. Bagi Institusi Kesehatan

Lebih meningkatkan kegiatan health education tentang pentingnya pemberian dan efek samping Imunisasi Campak terhadap bayi usia 9-12 tahun, sehingga dapat meningkatkan pengetahuan

kesehatan dan meningkatkan kesadaran serta penilaian para ibu sehingga tidak terjadi sikap yang salah dan cenderung membahayakan bayi.

2. Bagi peneliti selanjutnya

a. Diharapkan dapat mengembangkan penelitian tentang persepsi ibu dengan imunisasi campak dengan teknik sampel yang berbeda dan sampel yang lebih besar sehingga penilitian lebih baik.

b. Diharapkan dapat digunakan sebagai bahan masukan di dalam melakukan penelitian yang selanjutnya.

3. Bagi Responden

Diharapkan untuk ibu yang mempunyai persepsi negatif lebih mengubah panilaian dan pandangan terhadap Imunisasi Campak dan efek sampingnya, sehingga tidak menjadikan hal yang membahayakan bayi.

4. Bagi UNUSA

Perpustakaan UNUSA hendaknya melengkapi buku-buku yang bisa digunakan sebagai referensi dalam melakukan penelitian. Karena selama ini buku yang ada masih terbatas, edisi lama, khususnya buku tentang persepsi.

\section{DAFTAR PUSTAKA}

Alex, Sobur. (2009). Psikologi umum. Pustaka Setia, Bandung: hal : 446-497 
Branca, Woodworth dan Marquis, 2007, "Teori psikologi sosial". Jakarta:rajawalipers, Hlm 84

Departemen Kesehatan Republik Indonesia, (2015). Laporan Riset KesehatanDasar.2015.www.diskes.jati mprov.go.iddiakses pada tanggal 20 Februari 2016

Departemen Kesehatan Republik Iindonesia,(2014).Publisbang

Pemberantas Penyakit. Kematian balita disebabkan penyakit yang dapat dicegah dengan imunisasi, Jakarta. Diakses pada tanggal 21 Februari 2016

Hadinegoro, S. R. S. (2010) Pattern and immunitation factors of breastfeedingof working mothers in several areas in Jakarta. Peadiatr Indones, 47(1):27- 31.

Hermawato, Hery. 2010. Pengantar Psikologi Umum. Yogyakarta: EGC

Ranuh. I.G.N. 2008. Dasar-dasar imunisasi. dalam I.G.N. Ranuh, Hariyono suyitno, Sri Rezeki S Hadinegoro, Soedjatmiko: Pedoman imunisasi di indonesia. Edisi ketiga. Jakarta: Ikatan Dokter Anak Indonesia.

Ikatan Dokter Anak Indonesia. 2015. Jadwal imunisasi untuk bayi di puskesmas dan posyandu.http://www.idai.or.id/imunis asi.asp. 8 Maret 2016

Marimbi, Hanum, 2010. Tumbuh Kembang, Status Gizi dan Imunisasi Dasar Pada Balita. $\quad$ Yogyakarta: Nuha Medika
Maramis, Willy. F. (2006). Ilmu Perilaku Dalam Pelayanan Kesehatan. Surabaya: Airlangga University Press.

Maryunani, Anik. 2007. Asuhan pada ibu dalam pemberian imunisasi pada bayi. Jakarta: EGC

Nursalam. 2010. Konsep dan Penerapan Metodologi Penelitian Kesehatan. Jakarta: Rineka Cipta

Notoatmodjo, soekidjo, 2008. Promosi kesehatan dan Ilmu persepsi. Jakarta: Rineka Cipta

Nursalam. 2010. Teknik Pengambilan Sempel dalam Penelitian. Jakarta: EGC

Moeloek, Nila. 2015. Buku Panduan Kesehatan Ibu dan Anak (KIA) revisi. Jakarta. EGC

Robbins, Steepen. 2006. Sikap dan Perilaku Organisasi (Terjemahan Benyamin. M). Jakarta : PT. Binawan Pressindo.

Azwar, Saifudin. 2010. Teori Sikap dan Pengukurannya, Pustaka Pelajar, Yogyakarta : 155-157

Sugihartono, dkk. 2007. Psikologi Pendidikan. Yogyakarta: UNY Press

Sugiyono. 2010. Metode Penelitian Kuantitatif \& Kualitatif dan $R \& D$. Alfabeta, Bandung : 147

Sunaryo, 2007, Psikologi Untuk Keperawatan, EGC, Jakarta: 93-98

Suparyanto (2011). Konsep Imunisasi Dasar Lengkap. Jakarta: 26 September 2011 